\title{
Peran Masyarakat Terhadap Adopsi Inovasi Teknologi dalam Perencanaan Pembangunan Peternakan di Desa Watang Pulu, Kecamatan Suppa Kabupaten Pinrang Provinsi Sulawesi Selatan
}

\author{
The Role of the Community in Planning Livestock Development Regarding the Adoptionf \\ Technology in the Village of Watang Pulu, Suppa Subdistrict, \\ Pinrang Regency of South Sulawesi Province \\ Khaifah Asgaf \\ Jurusan Ilmu Peternakan Fakultas Sains dan Teknologi \\ Universitas Islam Negeri Alauddin Makassar \\ Korespondensi E-mail : khaifah.asgaf@uin-alauddin.ac.id
}

\begin{abstract}
ABSTRAK
Penelitian ini bertujuan untuk mengetahui sejauhmana peranan masyarakat dalam perencanaan pembangunan peternakan menyangkut adopsi teknologi di Desa Watang Pulu Kecamatan Suppa Kabupaten Pinrang.Metode yang digunakan dalam penelitian ini adalah kualitatif dengan proses FGD (Focus Group Discussion) secara mendalam dengan ketua kelompok tani/ternak dan anggotanya serta tokoh masyarakat dengan membahas tentang masalah yang ada dalam perencanaan peembangunan peternakan yang menyangkut adopsi inovasi teknologi di Desa Watang Pulu Kecamatan Suppa Kabupaten Pinrang.Hasil penelitian ini menunjukkan bahwa masalah yang sering melanda peternak yaitu penyakit, kurangnya nutrisi pakan, populasi ternak tinggi sementara tenaga kerja kecil dan fungsi lembaga berwenang yang kurang efektif. Dari masalah tersebut peneliti memberikan solusi adopsi inovasi teknologi yang berkaitan dengan masalah yang di hadapi peternak di desa tersebut.
\end{abstract}

Kata kunci: Peran Masyarakat, Adopsi Inovasi, Kabupaten Pinrang

\begin{abstract}
This study aims to determine the extent of the role of the community in planning livestock development regarding the adoption of technology in the village of Watang Pulu, Suppa Subdistrict, Pinrang Regency. The method used in this study is qualitative with an in-depth Focus Group Discussion process with the head of the farmer/ livestock group and its members and community leaders by discussing the problems that exist in livestock development planning concerning the adoption of technological innovations in Watang Pulu Village, Suppa District Pinrang Regency. The results of this study indicate that problems that often plague farmers are diseases, lack of nutritional feed, high livestock populations while small labor and less effective functions of authorized institutions. From these problems researchers provide solutions to the adoption of technological innovations related to the problems faced by farmers in the village.
\end{abstract}

Keywords: Adoption of Technology, Pinrang Regency, The Role of The Community, 


\section{PENDAHULUAN}

Ilmu dan teknologi merupakan hasil olah pikir manusia yang dipergunakan untuk memecahkan permasalahan-permasalahan yang dihadapi oleh manusia. Berbicara tentang teknologi peternakan, merupakan salah satu faktor penentu keberhasilan usaha peternakan, karena teknologi sebagai alat untuk mencapai tujuan peternakan disamping peternak sebagai subyek, ternak sebagai obyek, serta lahan dan lingkungan sebagai basis ekologi pengembangan peternakan.

Upaya yang dapat dilakukan untuk meningkatkan adopsi teknologi peternakan adalah memilih inovasi teknologi tepat guna yang memenuhi kriteria. Suatu inovasi tidak akan berguna tanpa adanya adopsi. Demikian juga dengan teknologi yang merupakan pendukung perencanaan pembangunan peternakan tidak akan berguna tanpa adanya adopsi. Mardikanto (2009) mendefinisikan adopsi sebagai proses perubahan perilaku yang berupa pengetahuan, sikap maupun keterampilan pada diri seseorang setelah menerima pesan yang di sampaikan penyuluh pada sasarannya.

Masyarakat dalam hal ini peternak bertanggung jawab dalam mengadopsi inovasi teknologi yang berkaitan dengan perencanaan pembangunan secara tepat sehingga pembangunan nasional dapat terwujud. Hal inilah yang melatarbelakangi dilakukannya penelitian perencanaan pembangunan peternakan tentang peran masyarakat terhadap adopsi inovasi teknologi dalam perencanaan pembangunan peternakan.

Tujuan dari penelitian perencanaan pembangunan peternakan adalah untuk mengetahui peran masyarakat terhadap adospi inovasi teknologi dalam perencanaan pembangunan peternakan di Desa Watang Pulu, Kecamatan Suppa, Kabupaten Pinrang.

\section{METODE}

Penelitian perencanaan pembangunan peternakan mengenai peran masyarakat terhadap adopsi inovasi teknologi dalam perencanaan pembangunan peternakan dilaksanakan selama 3 bulan yaitu dari bulan Mei-Juli 2017 yang bertempat di Desa Watang Pulu, Kecamatan Suppa, Kabupaten Pinrang, Provinsi Sulawesi Selatan.

\section{Jenis Dan Sumber Data}


Jenis dan sumber data yang digunakan dalam penelitian perencanaan pembangunan peternakan mengenai peran masyarakat terhadap adopsi inovasi teknologi dalam perencanaan pembangunan peternakan di Desa Watang Pulu, Kecamatan Suppa, Kabupaten Pinrang, Provinsi Sulawesi Selatan, antara lain :

a. Jenis data

Berdasarkan jenis data dapat dikelompokkan dalam dua jenis data ,yaitu :

1. Data primer adalah data yang diperoleh atau dikumpulkan secara langsung dari sumber datanya. Data primer disebut juga sebagai data asli atau data baru. Teknik yang dapat digunakan peneliti untuk mengumpulkan data primer antara lain observasi, wawancara, dan diskusi.

2. Data sekunder adalah data yang diperoleh atau dikumpulkan peneliti dari berbagai sumber yang telah ada. Data sekunder dapat diperoleh dari berbagai sumber seperti buku, laporan jurnal, profil desa dll.

b. Sumber data

Sumber data yang digunakan adalah wawancara. Wawancara adalah teknikpengumpulan data yang dilakukan dengan mengajukan pertanyaan secaralisan. Data yang dihasilkan adalah data primer.

c. Metode pengambilan data

Metode pengambilan data yang dilakukan dalam penelitian perencanaan pembangunan peternakan mengenai peran masyarakat terhadap adopsi inovasi teknologi dalam perencanaan pembangunan peternakan di Desa Watang Pulu, Kecamatan Suppa, Kabupaten Pinrang, Provinsi Sulawesi Selatan adalah metode wawancara. Yang dimaksud dengan wawancara adalah proses memperoleh keterangan untuk tujuan penelitian dengan cara tanya jawab sambil bertatap muka antara pewawancara dengan responden dengan cara intgerview. Wawancara dapat dilakukan dengan tatap muka

d. Kegiatan yang dilakukan

Kegiatan yang dilakukan dalam penelitian perencanaan pembangunan peternakan mengenai peran masyarakat terhadap adopsi inovasi teknologi dalam perencanaan pembangunan peternakan di Desa Watang Pulu, Kecamatan Suppa, Kabupaten Pinrang, Provinsi Sulawesi Selatan adalah Focus Group Discussion (FGD). Focus Group Discussion (FGD) merupakan suatu diskusi yang dilakukan secara sistematis dan terarah mengenai suatu diskusi yang dilakukan secara sistematis dan terarah mengenai suatu masalah tertentu. FGD 
dapat digunakan sebagai metode primer dan sekunder. FGD sebagai metode primer jika digunakan sebagai suatu metode utama pengumpulan data dalam suatu penelitian, sedangkan FGD sebagai metode sekunder umumnya digunakan untuk melengkapi data yang bersifat kuantitatif.

\section{HASIL DAN PEMBAHASAN}

\section{Kajian FGD Tentang Peran Masyarakat Terhadap Adopsi Inovasi Teknologi Dalam Perencanaan Pembangunan Peternakan.}

Berdasarkan hasil FGD yang dilakukan di kantor Lurah, Desa Watang Pulu, Kecamatan Suppa, Kabupaten Pinrang, Sulawesi selatan, maka diketahui bahwa masyarakat sangat antusias beternak sapi potong, karena dapat dilihat dari potensi desa, terdapat gunung sebagai lahan rumput, terdapat sawah sebagai yang dapat digunakan sebagai pakan saat pasca panen. Selain itu pemerintah juga turut mendukung sektor peternakan dengan bantuan dana dan obat-obatan.

Potensi Desa Watang Pulu, Kecamatan Suppa, Kabupaten Pinrang, Sulawesi selatan sangat besar jika dikembangkan dengan baik, dengan adanya teknologi peternakan. Namun kebanyakan masyarakat kurang tahu tentang bagaimana teknologi yang disarankan untuk perkembangan pembangunan peternakan. Hal ini sesuai dengan pendapat Abbas (2017). Bahwa dalam pembuatan usaha peternakan dibutuhkan tempat yang berpotensi agar dapat berkembang usaha tersebut. Berdasarkan hasil diskusi dengan metode FGD diperoleh data pada Tabel 1.

Berdasarkan data pada Tabel 1, diketahui bahwa daerah ini memiliki musim kawin mulai dari bulan April sampai dengan bulan Mei. Yang dimana masih berlangsung musim hujan. Sebenarnya musim kawin pada bulan april kurang tepat karena saat nantinya melahirkan terjadi pada musim kemarau. Sehingga pakan hijauan berkurang. Hal ini akan berpengaruh pada susu yang dihasilkan sang induk sehingga pengaruhnya sangat kuat terhadap pertumbuhan anaknya.

Pada Tabel 1. dapat dilihat bahwa musim panen dilakukan pada bulan mei dan juni, dimana kedua bulan ini musim hujan masih berlangsung. Hal ini berdampak pada kualitas gabah yang dihasilkan karena proses pengeringan yang tidak sempurna. Masalah yang juga biasa terjadi pada desa Watang Pulu yaitu penyakit pada ternak sapi. Musim penyakit pada ternak sapi biasanya terjadi pada peralihan musim/cuaca. Musim penyakit pada tabel 30 
menunjukkan pada bulan, januari, juli dan September. Menurut Pak Hasanuddin, penyakit yang sering menyerang sapi yaitu penyakit mata dan kekurusan. Sementara musim pakan teijadi dibulan januari sampai desember ( sepanjang tahun selalu ada) pada musim hujan sampai memproleh pakan di daerah gunung, sedangkan pada musim kemarau sapi memproleh pakan di sawah saat pasca panen, akan tetapi nutrisi jerami pakan dimusim kemarau kurang memenuhi karena pakan mulai mengering.

Tabel 1. Kalender Musim Desa Watang Pulu, Kecamatan Suppa, Kabupaten Pinrang

\begin{tabular}{|c|c|c|c|c|c|c|c|c|c|c|c|c|c|}
\hline \multirow{2}{*}{ No } & \multirow{2}{*}{ Musim } & \multicolumn{5}{|c|}{ Bulan } & \multirow[b]{2}{*}{6} & \multirow[b]{2}{*}{7} & \multirow[b]{2}{*}{8} & \multirow[b]{2}{*}{9} & \multirow[b]{2}{*}{10} & \multirow[b]{2}{*}{11} & \multirow[b]{2}{*}{12} \\
\hline & & 1 & 2 & 3 & 4 & 5 & & & & & & & \\
\hline 1 & Musim Kawin & & & & & & & & & & & & \\
\hline 2 & Musim Panen & & & & & & & & & & & & \\
\hline 3 & Musim Penyakit & & & & & & & & & & & & \\
\hline 4 & Musim Pakan & & & & & & & & & & & & \\
\hline 5 & Musim Lahir & & & & & & & & & & & & \\
\hline 6 & Musim Kemarau & & & & & & & & & & & & \\
\hline 7 & Musim Hujan & & & & & & & & & & & & \\
\hline
\end{tabular}

Musim lahir terjadi seringkali dimusim kemarau, menurut Pak Hasanuddin salah satu peserta Musrembangdes, mengatakan bahwa musim lahir biasanya teijadi dibulan maret sampai bulan april, dimana masih berlangsung musim hujan. Pada musim ini sangat baik karena ketersediaan pakan untuk memenuhi kebutuhan nutrisi ternak sangat berlimpah dimusim hujan.

Musim kemarau, menurut Pak Hasanuddin, musim kemarau terjadi pada bulan agustus sampai oktober. Menurut Badan Meteoreologi dan geofisika, musim kemarau terjadi pada bulan april hingga September. Pada musim kemarau peternak memanfaatkan area persawahan yang telah dipanen sebagai tempat penggembalaan sapi.

Masalah yang terakhir adalah musim penghijauan yang mulai pada bulan januari sampai juni. Selama musim hujan, peternak mengembalakan sapinya secara ekstensif dibuat karena hijauan yang masih berlimpah. Para peternak membawa sapinya kembali ke gunung mulai pukul 06.00 dan pulang pukul 16.00 peternak mengendap sapinya pada malam hari tapi hal tersebut sangat jarang dilakukan. Hal ini sesuai dengan pendapat Rudy (2012), 
bahwa musim tersedia pakan yang berlimpah sementara saat kemarau ketersediaan pakan sangat berkurang.

\section{Analisis masalah}

Berdasarkan hasil diskusi yang telah dilakukan di kantor lurah Tellumpanua Kec. Suppa Kab. Pinrang Sulawesi Selatan, melalui Forum Group Discution (FGD) bersama salah satu peserta yakni Pak Hasanuddin. Beliau mengatakan bahwa masalah-masalah yang sering kali dihadapi peternak di desa tersebut adalah, penyakit ternak, kekurangan nutrisi pakan, kandang, populasi ternak, tenaga keija dan kelembagaan.

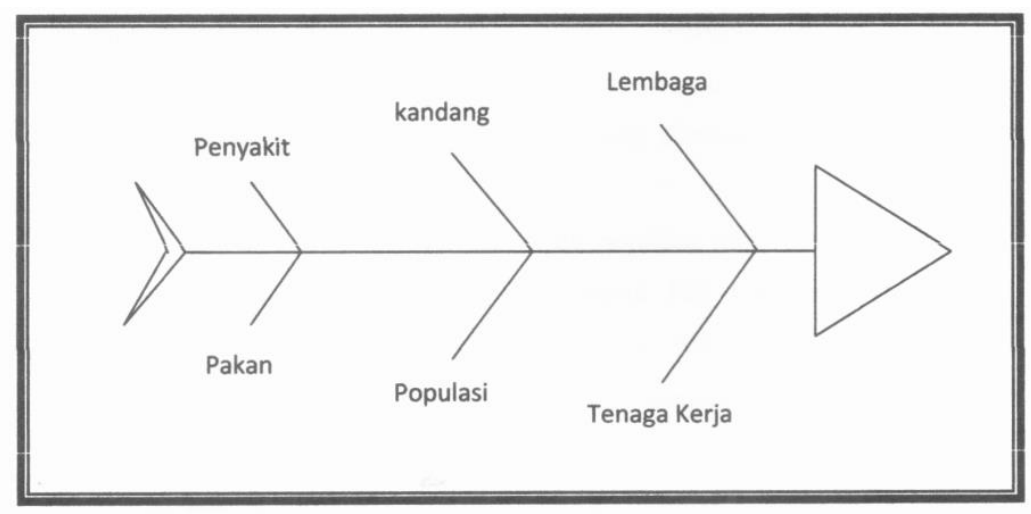

Gambar 1. Analisis Masalah

Di desa Tellumpanua dan desa Watang Pulu Kec. Suppa Kab. Pinrang Sulawesi Selatan, penyakit yang sering menyerang ternak yaitu, penyakit mata dan cacingan (kekurusan). Menurut Pak Hasanuddin penyakit tersabut sering datang saat peralihan musim, baik musim hujan ke musim kemarau ataupun musim kemarau ke musim hujan.

Masalah yang kedua yaitu pakan. Di desa Tellumpanua dan Watang Pulu Kec. Suppa Kab. Pinrang Sulawesi Selatan, pakan sselalu tersedia sepanjang tahun. Saat musi hujan sapi di giring ke pegunungan untuk digembalakan, karena pakan di pegunungan berlimpah. Saat musim kemarau sapi kembali ke persawahan. Akan tetapi nutrisi pakan saat musim kemarau sangat rendah. Hal tersebut karena sapi hanya dapat memakan jerami padi yang sudah kering.

Masalah ketiga yaitu kandang bagi ternak. Di desa Tellumpanua dan Watang Pulu Kec. Suppa Kab. Pinrang Sulawesi Selatan, para peternak hanya mengembalakan ternaknya di alam bebas, seperti di persawahan dan pegunungan. Menurut Pak Hasanuddin ternak 
bukannya tidak memiliki kandang, akan tetapi kandang yang ada tidak layak bagi ternak (masak). Kadang digunakan saat hujan lebat dan saat melakukan penjualan.

Masalah ke empat dan kelima yaitu, populasi ternak yang cukup besar sementara tenaga kerja sangat kurang. Menurut Pak Hasanuddin, sapi yang ditangani di kelompok taninya berjumlah sekitar 100 ekor. Sementara tenaga kerjanya hanya 3 orang. Masalah lain mengenai populasi sapi yaitu kurangnya pejantan dalam populasi tersebut. Menurut tamrin salah satu peserta FGD mengatakan bahwa sapi yang ada di kelompok taninya berjumlah 24 ekor dan semuanya betina. Sehingga untuk melakukan perkawinan sangat sulit.

Masalah ke enam mengenai kelembagaan. Kelembagaan pertanian peternakan di Tellumpanua dan Watang Pulu Kec. Suppa Kab. Pinrang Sulawesi Selatan ini belum maksimal dalam membantu dan memfasilitasi peternak atau dengan kata lain bahwa kelembagaan belum bekerja maksimal. Menurut Pak Hasanuddin kelembagaan terkait telah berjalan seperti pemberian obat dan vaksin, pemeriksaan kebuntingan pada sapi. Akan tetapi terkadan telat. Terkadang 1-2 tahun sekali. Selain itu penyuluh dari lembaga yang berwenang hanya menyampaikan dan tidak ada kelanjutan dalam proses pembimbingan peternak.

\section{Strategis dan Program Perencanaan yang Diusulkan.}

Berdasarkan musrembangdes atau FGD yang telah dilakukan di kantor lurah Tellumpanua Kec. Suppa Kab. Pinrang Sulawesi Selatan. Diketahui bahwa masalah yang masalah yang sering melanda peternak yaitu, penyakit, kurangnya nutrisi pakan, populasi ternak tinggi sementara tenaga kerja kecil dan fungsi lembaga berwenang yang kurang efektif.

Solusi terkait materi Perencanaan Pembangunan Peternakan kami, yaitu Peran Masyarakat terhadap Adopsi Inovasi Teknologi dalam Pembangunan Peternakan. Mengenai masalah pakan, kami mengusulkan teknologi Fermentasi Jerami sebagai alternatif peningkatan nutrisi pakan. Fermentasi jerami padi dapat meningkatkan protein yang terkandung di dalam jerami yang kering sehingga mampu menutupi kebutuhan nutrisi ternak. Selain itu potensi desa Tellumpanua dan Watang Pulu Kec. Suppa Kab. Pinrang Sulawesi Selatan sangat mendukung program teknologi ini. karena persawahan di daerah ini sangat banyak persawahan. Hal ini sesuai dengan pendapat Agustina (2007), Bahwa jerami padi sebagai pakan perlu dilakukan sentuhan teknologi untuk meningkatan kualitas jerami padi. Jerami padi sebagai makanan ternak masih memiliki keterbatasan yang 
disebabkan oleh tingginya kandungan silika dan rendahnya kandungan zat makanan seperti protein yang dibutuhkan oleh ternak. Karakteristik jerami padi ditandai dengan rendahnya kandungan nitrogen dan mineral esensial, sedang serat kasamya yang tinggi sehingga kecemaannya hanya mencapai $37 \%$. Teknologi yang baik digunakan oleh peternakan dalam mengatasi masalah pakan adalah fermentasi jerami.

Dalam mengatasi masalah populasi ternak mengenai kurangnya ternak sapi pejantan, dimana betina sangat mendominasi bahkan dalam satu populasi ternak di satu kelompok tani memiliki ternak sapi betina saja sehingga perkawinan sulit teijadi. Mengenai hat itu. kami mengusulkan Teknologi Inseminasi Buatan (IB) untuk lebih mudah dalam proses pembuntingan sapi dan mendorong peternakan lebih berkembang. Hal ini sesuai dengan pendapat Balai Besar Pelatihan Peternakan (2017), bahwa Inseminasi Buatan (IB) atau dalam istilah ilmiahnya disebut Artificial Insemination (AI) merupakan sistem perkawinan pada ternak sapi secara buatan yakni suatu cara atau teknik memasukkan sperma atau semen kedalam kelamin sapi betina sehat dengan menggunakan alat inseminasi yang dilakukan oleh manusia (Inseminator) dengan tujuan agar sapi tersebut menjadi bunting.

Diharapkan program-program yang diusulkan dalam Perencanaan Pembangunan Peternakan dapat menyelesaikan permasalan-permasalan yang dihadapi peternak di desa Tellumpanua dan Watang Pulu Kec. Suppa Kab. Pinrang Sulawesi Selatan. Sehingga dalam mencapai tujuan dan cita-cita peternak akan peningkatan pendapatan usaha peternakan dan majunya peternakan yang digeluti dapat di peroleh dengan baik.

\section{KESIMPULAN}

Berdasarkan penelitian yang dilakukan mengenai perencanaan pembangunan peternakan di Desa Watang Pulu, Kecamatan Suppa, Kabupaten Pinrang, Provinsi Sulawesi Selatan maka dapat ditarik kesimpulan bahwa :

1. Masalah yang dihadapi di Desa ini adalah pakan berkualitas rendah, populasi ternak yang tinggi sementara tenaga kerja rendah, kelembagaan yang kurang, penyakit dan masalah perkandangan

2. Program yang di rencanakan dalam pembangunan peternakan di Desa tersebut yaitu teknologi fermentasi jerami dan insiminasi buatan (IB) 
Agar kiranya masyarakat dapat lebih meningkatkan peranannya dalam adopsi inovasi teknologi untuk perencanaan pembangunan peternakan di desanya agar dapat lebih sejahtera.

\section{DAFTAR PUSTAKA}

Agustina. 2007. Perlunya Peningkatan Adopsi Teknologi Peternakan. (Online), (http:/ / inaabdullah.blogspot.eom/2008/11/perlunya-peningkatan-adopsiteknologi.html, diakses tanggal 7 Oktober 2017).

Mardikanto. 2009. Sistem Penyuluhan Pertanian. Sebelas Maret University Press, Surakarta.

Progo. 2011. Penerapan Adopsi Inovasi Teknologi. (Online), (http://studyeleming.blogspot.com/2011/12/adopsi-inovasi.html, diakses tanggal 7 Oktober 2017).

Ridha, Insan. 2012. Makalah Proses Adopsi dan Inovasi Pertanian. (Online), (http:/ / ullillallullellou.blogspot.com/2012/12/makalah-proses-adopsi-dan inovasi.html, diakses tanggal 7 Oktober 2017).

Rogers dan Shoemaker. 1971. Kecepatan Adopsi dan Tingkatan Penerapan Teknologi. BPPT Press, Jakarta.

Rosyidin. 2017. Kajian Peran Peternakan Pembangunan. (Online) (http:/ / rosyidin.wordpress.ac.id, diakses tanggal 7 Oktober 2017). 